\title{
Chemoselective Transfer Hydrogenation of $\alpha, \beta$-Unsaturated Ketones Catalyzed by Iridium Complexes
}

\author{
Yanping Xia \\ Lu Ouyang \\ Jianhua Liao \\ Xiao Yang \\ Renshi Luo* (1) \\ School of Pharmacy, Gannan Medical University, Ganzhou, \\ 341000, Jiangxi Province, P. R. of China \\ luorenshi2010@163.com
}

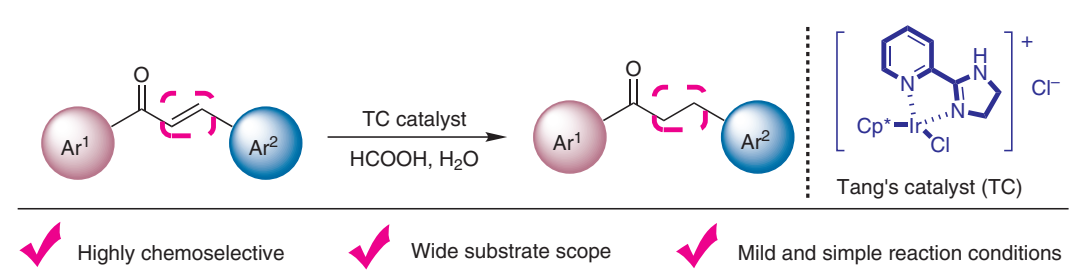

Received: 29.12.2020

Accepted after revision: 26.01.2020

Published online: 08.02 .2020

DOI: 10.1055/s-0040-1706022; Art ID: so-2020-d0049-I

License terms: cc)

(c) 2021. The Author(s). This is an open access article published by Thieme under the terms of the Creative Commons Attribution-NonDerivative-NonCommercial-License, permitting copying and reproduction so long as the original work is given appropriate credit. Contents may not be used for commercial purposes or adapted, remixed, transformed or built upon. (https://creativecommons.org/licenses/by-nc-nd/4.0/)

Abstract Efficient chemoselective transfer hydrogenation of the $\mathrm{C}=\mathrm{C}$ bond of $\alpha, \beta$-unsaturated ketones has been developed, using the iridium complexes containing pyridine-imidazolidinyl ligands as catalysts and formic acid as a hydrogen source. In comparison with organic solvents or $\mathrm{H}_{2} \mathrm{O}$ as solvent, the mixed solvents of $\mathrm{H}_{2} \mathrm{O}$ and $\mathrm{MeOH}$ are critical for a high catalytic chemoselective transformation. This chemoselective transfer hydrogenation can be carried out in air, which is operationally simple, allowing a wide variety of $\alpha, \beta$-unsaturated substrates with different functional groups (electron-donating and electron-withdrawing substituents) leading to chemoselective transfer hydrogenation in excellent yields. The practical application of this protocol is demonstrated by a gram-scale transformation.

Key words transfer hydrogenation, iridium complex, $\alpha, \beta$-unsaturated ketones, formic acid, chemoselective reduction

Saturated carbonyl compounds are ubiquitous, and many pharmaceutically active molecules contain 1,3-diaryl ketones (Figure 1). ${ }^{1}$<smiles>CCCNCC(O)COc1ccccc1C(=O)CCc1ccccc1</smiles>

(R)-propafenone

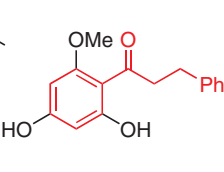

uvangoletin

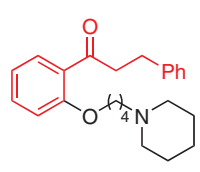

GPV 195
Figure 1 Examples of pharmaceutically active molecules containing 1,3-diaryl ketones

Among the methodologies for the synthesis of saturated carbonyl compounds, one of the best ways is the selective reduction of carbon-carbon double bonds on $\alpha, \beta$-unsaturated carbonyl compounds. ${ }^{2}$ However, chemoselective reduction of carbon-carbon double bonds of $\alpha, \beta$-unsaturated carbonyl compounds wherein the carbon-oxygen double bond is not affected, ${ }^{3}$ is a challenge with a significant role in organic synthesis. ${ }^{4}$

Traditional transformation of chemoselective reduction of $C=C$ bonds of $\alpha, \beta$-unsaturated carbonyl compounds include hydrogenation with hydrogen over a Pd/C catalyst. ${ }^{5}$ It is well known that transition metals are not only good electron donors, but also electron acceptors due to the availability of vacant d-orbitals that possess specific electronic and spatial effects when coordinated with organic ligands. ${ }^{6}$ Therefore, much effort has been devoted to the development of highly chemoselective reduction of $\mathrm{C}=\mathrm{C}$ bonds for $\alpha, \beta$-unsaturated carbonyl compounds catalyzed by transition-metal catalysts, such as $\mathrm{Pd},{ }^{2 \mathrm{~d}, 7} \mathrm{Rh},{ }^{8} \mathrm{Ru},{ }^{2 c, e, f} \mathrm{Ni}^{2 \mathrm{~b}, 9} \mathrm{Ir}^{10}$ $\mathrm{Co}^{11}$ and Fe (Scheme 1a). ${ }^{12}$ At the same time, nontransition-metal hydrides such as $\mathrm{Sn}, \mathrm{Se}, \mathrm{Te}, \mathrm{B},{ }^{13}$ and others ${ }^{14}$ have

\section{(a) Previous work: Transition-metal reduction of $\mathrm{C}=\mathrm{C}$ bond in $\alpha, \beta$-unsaturated} carbonyl compounds

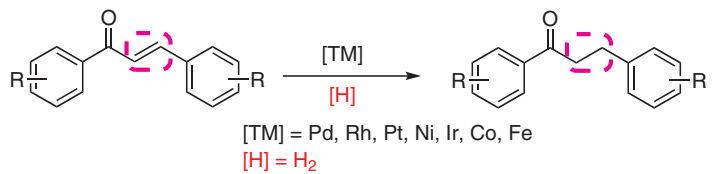

(b) This work: Iridium complex catalyzed selective reduction of $\mathrm{C}=\mathrm{C}$ bond in $\alpha, \beta$-unsaturated carbonyl compounds

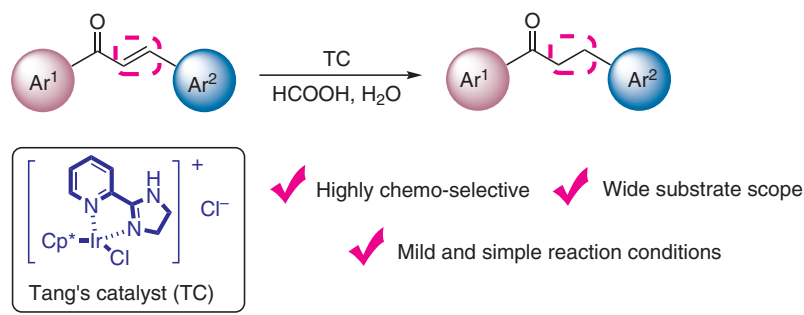

Scheme 1 Selective reduction of the $C=C$ bond of $\alpha, \beta$-unsaturated carbonyl compounds 
also been employed for the selective reduction of $\mathrm{C}=\mathrm{C}$ bonds in $\alpha, \beta$-unsaturated carbonyl compounds. Furthermore, enzymic reduction is receiving increasing attention due to the potential for high chemoselectivity.

However, most of transition metals and their metal complexes are expensive, and the methodology is difficult to realize at industrial scale. Meanwhile, hydrogen is usually employed as the reductant, often under high pressures. ${ }^{15}$ Besides these drawbacks, other disadvantages of these methodologies may include harsh reaction conditions, long reaction time, low yields, and low functional group selectivity, limiting their applications in organic synthesis. Therefore, more general, practical, mild, and efficient methods for the selective reduction of the $C=C$ bond in $\alpha, \beta$-unsaturated carbonyl compounds without affecting the $\mathrm{C}=\mathrm{O}$ bond remain highly desirable.

Transfer hydrogenation is a well-established and efficient protocol that has the advantage of not requiring special equipment or hydrogen gas. Recently, our group developed iridium complex catalyzed transfer hydrogenation of $\mathrm{C}=\mathrm{O}$ and $\mathrm{C}=\mathrm{N}$ bonds by using formic acid or formate as the hydride source. ${ }^{16}$ As far as we know, reports on iridium complex catalyzed transfer hydrogenation of $\mathrm{C}=\mathrm{C}$ bonds remain limited. ${ }^{17}$ Therefore, we examined the iridium complex catalyzed chemoselective transfer hydrogenation of the $C=C$ bond of $\alpha, \beta$-unsaturated carbonyl compounds by

Table 1 Optimization of Reaction Conditions ${ }^{\mathrm{a}}$

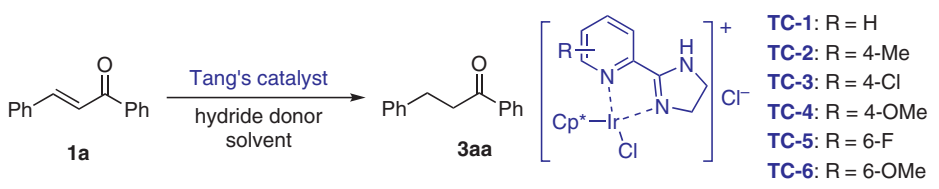

\begin{tabular}{|c|c|c|c|c|}
\hline Entry & Catalyst & Hydrogen donor & Solvent & Yield (\%) \\
\hline 1 & TC-1 & $\mathrm{HCOOH}$ & $\mathrm{H}_{2} \mathrm{O}$ & 60 \\
\hline 2 & TC-2 & $\mathrm{HCOOH}$ & $\mathrm{H}_{2} \mathrm{O}$ & 45 \\
\hline 3 & TC-3 & $\mathrm{HCOOH}$ & $\mathrm{H}_{2} \mathrm{O}$ & 49 \\
\hline 4 & TC-4 & $\mathrm{HCOOH}$ & $\mathrm{H}_{2} \mathrm{O}$ & 55 \\
\hline 5 & TC-5 & $\mathrm{HCOOH}$ & $\mathrm{H}_{2} \mathrm{O}$ & 52 \\
\hline 6 & TC-6 & $\mathrm{HCOOH}$ & $\mathrm{H}_{2} \mathrm{O}$ & 57 \\
\hline 7 & TC-1 & HCOONa & $\mathrm{H}_{2} \mathrm{O}$ & 48 \\
\hline $8^{c}$ & TC-1 & $\mathrm{HCOOH} / \mathrm{Et}_{3} \mathrm{~N}$ & $\mathrm{H}_{2} \mathrm{O}$ & 42 \\
\hline $9^{d}$ & TC-1 & $\mathrm{HCOOH}$ & $\mathrm{H}_{2} \mathrm{O}$ & 63 \\
\hline 10 & TC-1 & $\mathrm{HCOOH}$ & DMF & 43 \\
\hline 11 & TC-1 & $\mathrm{HCOOH}$ & toluene & 51 \\
\hline 12 & TC-1 & $\mathrm{HCOOH}$ & THF & 46 \\
\hline 13 & TC-1 & $\mathrm{HCOOH}$ & $\mathrm{CH}_{2} \mathrm{Cl}_{2}$ & 57 \\
\hline 14 & TC-1 & $\mathrm{HCOOH}$ & $\mathrm{MeCN}$ & 48 \\
\hline 15 & TC-1 & $\mathrm{HCOOH}$ & $\mathrm{MeOH}$ & 57 \\
\hline $16^{\mathrm{e}}$ & TC-1 & $\mathrm{HCOOH}$ & $\mathrm{H}_{2} \mathrm{O}$ & 69 \\
\hline $17^{f}$ & TC-1 & $\mathrm{HCOOH}$ & $\mathrm{H}_{2} \mathrm{O} / \mathrm{CH}_{2} \mathrm{Cl}_{2}$ & 80 \\
\hline $18^{g}$ & TC-1 & $\mathrm{HCOOH}$ & $\mathrm{H}_{2} \mathrm{O} / \mathrm{MeOH}$ & 90 \\
\hline $19^{\mathrm{h}}$ & TC-1 & $\mathrm{HCOOH}$ & $\mathrm{H}_{2} \mathrm{O} / \mathrm{MeOH}$ & $93(90)$ \\
\hline $20^{i}$ & TC-1 & $\mathrm{HCOOH}$ & $\mathrm{H}_{2} \mathrm{O}$ & 12 \\
\hline $21^{\mathrm{j}}$ & TC-1 & $\mathrm{HCOOH}$ & - & 5 \\
\hline
\end{tabular}

a Reaction conditions: 1 a $(0.5 \mathrm{mmol})$, solvent $(2 \mathrm{~mL})$, catalyst (1 mol\%), hydrogen donor (10 equiv) at room temperature under air for $12 \mathrm{~h}$.

${ }^{b}$ Determined by GC-MS using dodecane as the internal standard. The number in parentheses is the isolated yield.

c The reaction was carried out with 5.0 equiv of $\mathrm{HCOOH}, 2.0$ equiv of $\mathrm{Et}_{3} \mathrm{~N}$.

d The reaction was carried out under $\mathrm{N}_{2}$ atmosphere.

e The reaction was carried out at $80^{\circ} \mathrm{C}$.

${ }^{\mathrm{f}} \mathrm{CH}_{2} \mathrm{Cl}_{2}(1 \mathrm{~mL})$ was added in the reaction.

${ }^{\mathrm{M}} \mathrm{MeOH}(1.0 \mathrm{~mL})$ was added in the reaction.

${ }^{\mathrm{h}} \mathrm{MeOH}(2 \mathrm{~mL})$ was added in the reaction.

i 2 equiv $(n-\mathrm{Bu})_{4} \mathrm{NBr}$.

j This reaction in only formic acid. 
adjusting the structures of the catalysts and hydrogen source. To achieve this goal, two problems needed to be settled: the effective catalytic system to realize $\mathrm{C}=\mathrm{C}$ bond reduction and the suppression of side reactions. Herein, we describe an efficient and practical iridium complex catalyzed chemoselective transfer hydrogenation of the $C=C$ bond of $\alpha, \beta$-unsaturated carbonyl compounds.

In the initial attempts at selective reduction of $\alpha, \beta$-unsaturated ketones, chalcone was used as model substrate, iridium complexes as catalysts, and $\mathrm{HCOOH}$ as hydrogen source at room temperature under air (Table 1 ). Interestingly, the desired product 3aa was afforded in a yield of $60 \%$ with the TC-1 catalyst (entry 1 ). To explore better catalytic system, several other of Tang's catalysts with different substituted functional groups were also screened (entries 2-6). Disappointedly, lower catalytic activities were obtained. As different hydride sources have important effects on transfer hydrogenation, other candidates were employed in this catalytic system. However, lower yields were obtained by using $\mathrm{HCOONa}$ and $\mathrm{HCOOH} / \mathrm{NEt}_{3}$ as hydride sources (entries 7 and 8). We also performed the reaction under $\mathrm{N}_{2}$ under standard conditions, but this showed no obvious improvement (entry 9). During our study, we observed that the substrate did not dissolve in the water. Therefore, a screening of organic solvents was performed. As shown (Table 1, entries 10-15), only moderate yields were achieved in organic solvents. However, at the same time, we also found that the solubility of $\mathbf{1 a}$ in organic solvents was different. For example, $\mathrm{MeOH}$ and $\mathrm{CH}_{2} \mathrm{Cl}_{2}$ can dissolve 1a completely, while it did not dissolve in DMF. Furthermore, when the reaction was performed in water, a white suspension was observed on the water surface, which was characterized by NMR spectroscopy and found to be unreacted starting material 1a. A higher reaction temperature led to slightly better conversion (entry 16). In our previous study, we knew that the catalysts had the features of excellent water solubility. Based on our previous research and above results, we envisaged that mixed solvents could help to improve catalytic activity. With this in mind, mixed solvents were next tested. To our satisfaction, high yields of 3aa were achieved in a mixture of $\mathrm{H}_{2} \mathrm{O}$ and $\mathrm{MeOH}$ under the standard conditions (entries 17-19). A phase-transfer catalyst such as quaternary ammonium salt $\left((n-\mathrm{Bu})_{4} \mathrm{NBr}\right)$ was used in just water, but only $12 \%$ of desired product was detected (entry 20 ). When using formic acid as hydrogen source and solvent, only a $5 \%$ yield of 3aa was obtained (entry 21).

Intrigued by this simple and efficient procedure for the selective reduction of $\mathbf{1 a}$, we then explored the substrate scope under the optimized transfer hydrogenation conditions (Scheme 2). In general, electron-donating and electron-withdrawing substituents on the phenyl ring ( $\beta$ to carbonyl group) and benzoyl rings are well tolerated and furnished the desired products in good yields (Scheme 2). For example, the substrate with a phenyl ring $\beta$ to the carbonyl

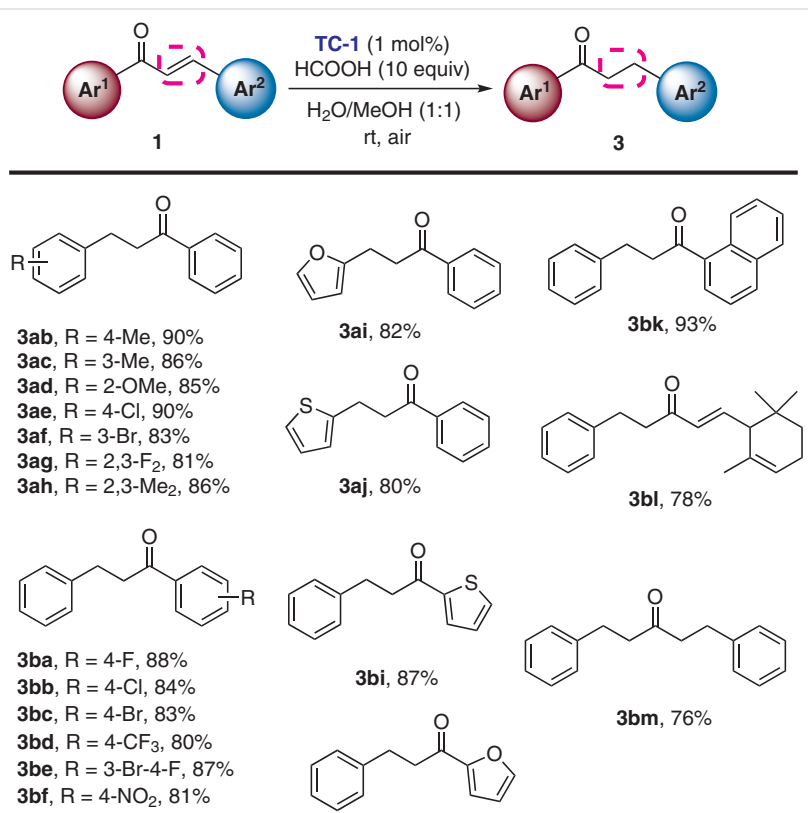

3bg, $R=4-\mathrm{Me}, 90 \%$

3bh, $\mathrm{R}=3-\mathrm{MeO}, 92 \%$

$3 \mathbf{b j}, 81 \%$

Scheme 2 Substrate scope. Reagents and conditions: 1 (0.5 mmol), TC-1 (1.0 mol\%), and $\mathrm{HCOOH}$ (10.0 equiv) in $\mathrm{H}_{2} \mathrm{O}(2.0 \mathrm{~mL})$ and $\mathrm{MeOH}$ $(2.0 \mathrm{~mL})$, room temperature, air, $12 \mathrm{~h}$. Yield of isolated product.

group contains substituents such as $p$-methyl, methoxy, chloride, fluoride, and bromide provided good to excellent yields of the corresponding products under standard conditions (3ab-ah). Notably, substrates with heterocyclic rings such as furyl, thiophenyl, and naphthyl also reacted smoothly and gave the desired products in high yields (3ai,aj).

To explore the utility of this iridium-catalyzed chemoselective transfer hydrogenation further, we also examined substrates with different substituents on the benzoyl ring. A variety of chalcones with halogen substituents on the benzoyl ring were selectively reduced in good yields (3babc,be). Substrates with strongly electron-drawing groups on the benzoyl ring, such as trifluoromethyl and nitryl, were selectively reduced to give the desired substituted ketones in yields of $80 \%$ and $81 \%$, respectively (3bd,bf). Substrates possessing methyl and methoxy groups on the benzoyl ring also reacted under the optimized conditions ( $\mathbf{3 b g}, \mathbf{b h})$. Of note, heterocyclic acyl substrates were also observed to be well-tolerated under the standard conditions, giving $\mathbf{3 b i}$ and $\mathbf{3 b j}$ in $87 \%$ and $81 \%$ yields, respectively. In addition, the sterically hindered 1-naphthoyl substrate (2bk) led to the successful synthesis of $\mathbf{3 b k}$. In addition, the doubly unsaturated substrate $\mathbf{2 b l}$ with a $\beta$-aryl and $\beta$-cylcohexenyl substituent gave $\mathbf{3 b l}$ efficiently, which demonstrates that unsaturated double bonds contiguous with a $\beta$-aryl group can also be reduced selectively. In keeping with this 
observation, when dibenzylideneacetone was employed as the substrate, the corresponding doubly reduced product $\mathbf{3 b m}$ could be obtained in a yield of $76 \%$.

In order to verify the practical synthetic application of this chemoselective transfer hydrogenation reduction of $\alpha, \beta$-unsaturated ketones, a scaled-up experiment was conducted. When 1a (10 mmol) was carried out under above established conditions, 3aa was isolated by flash chromatography in a yield of $88 \%$ (Scheme 3).<smiles>O=C(/C=C/c1ccccc1)c1ccccc1</smiles>

1a, $10 \mathrm{mmol}$

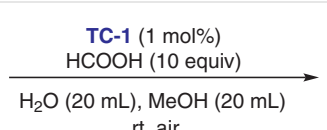

rt, air

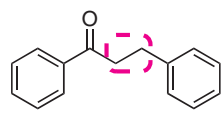

3aa, $88 \%, 1.85$
Scheme 3 Gram-scale experiment

Alcohols are usually employed as the proton source for transfer hydrogenation reduction ${ }^{18}$ and are preferred as a convenient, economical, and environmentally relatively benign choice. In this catalytic system, the hydride and proton sources are derived from formic acid and methanol. To gain more insight into this catalytic system, deuterium-labeling experiments were performed (Scheme 4). By using $\mathrm{D}_{2} \mathrm{O}$ as solvent, the ratio of $\mathrm{H} / \mathrm{D}$ at $\mathrm{C} 2$ was found to be $61: 39$ and $\mathrm{C} 1$ was not deuterated. The deuterium incorporation at $\mathrm{C} 2$ may be caused by $\mathrm{H}-\mathrm{D}$ exchange between [Ir]-H and $\mathrm{D}_{2} \mathrm{O}$. However, the outcome was quite different when $\mathrm{DCO}_{2} \mathrm{D}$ was employed. By using $\mathrm{DCO}_{2} \mathrm{D}$ instead of $\mathrm{HCOOH}$ under standard reaction conditions, product 3aa was afforded in 90\% yield with a $\mathrm{C} 1$ ratio of $\mathrm{H} / \mathrm{D}$ of $44: 56$, with no deuteration at $\mathrm{C} 2$.

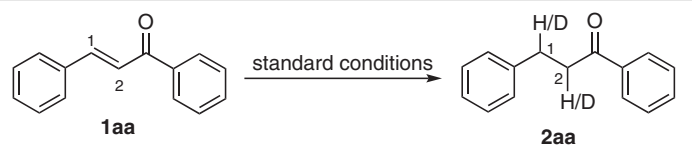

(a) $\mathrm{D}_{2} \mathrm{O}$ instead of $\mathrm{H}_{2} \mathrm{O}$

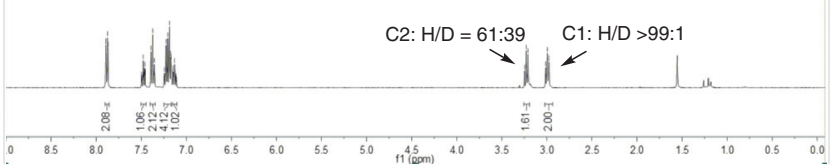

(b) $\mathrm{DCOOC}$ instead of $\mathrm{HCOOH}$

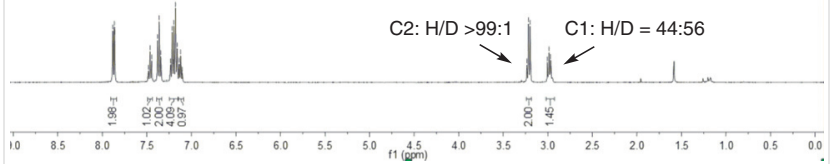

(c) $\mathrm{D}_{3} \mathrm{COD}$ instead of $\mathrm{CH}_{3} \mathrm{OH}$

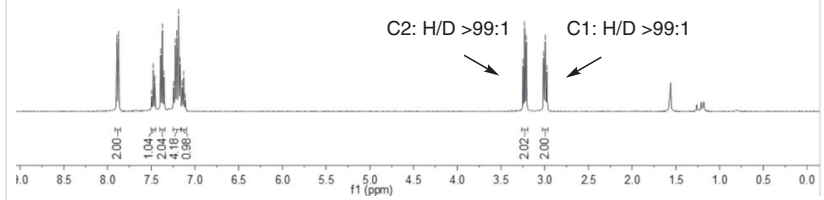

Scheme 4 Mechanistic studies
Again, the incomplete deuterium incorporation at $\mathrm{C} 1$ may be caused by $\mathrm{H}-\mathrm{D}$ exchange between [Ir]-D and $\mathrm{H}_{2} \mathrm{O}$. When $\mathrm{D}_{3} \mathrm{COD}$ was employed, efficient preparation of 3aa was observed without deuterium incorporation.

Based on the above control experiments, we propose the following mechanism (Scheme 5). Initially, the Ir hydride (Int-II) complex is formed by ligand exchange from Tc-1 with $\mathrm{HCOOH}$ followed by release of carbon dioxide. ${ }^{19}$ Then, the Ir hydride species coordinates with substrate 1a to generate Int-III, followed by the insertion of the polar $\mathrm{C}=\mathrm{C}$ bond to generate Int-IV. ${ }^{20}$ Finally, the desired product 3aa is achieved by ligand exchange of Int-IV, from which Int-II is released for the next catalytic cycle.

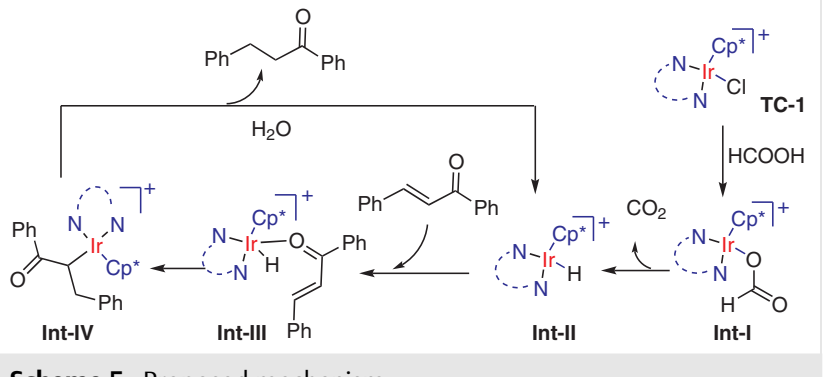

Scheme 5 Proposed mechanism

In conclusion, we have developed an iridium-catalyzed chemoselective transfer hydrogenation of the $\mathrm{C}=\mathrm{C}$ bond of chalcones to prepare 1,4-diaryl ketones in good to excellent yields by using formic acid as hydrogen source. ${ }^{21}$ The broad substrates scope, simple operation, and high chemoselectivity are the attractive features of this transformation. Further investigations as well as exploration of asymmetric transfer hydrogenation are in progress.

\section{Funding Information}

The authors thank the National Natural Science Foundation of China (Grant No. 21962004 and 21562004), the Jiangxi Provincial Department of Science and Technology (Grant No. 20192BAB203004), the Fundamental Research Funds for Gannan Medical University (Grant No. QD201810), and the COVID-19 Emergency Project of Gannan Medical University (Grant No. YJ202027) for financial support.

\section{Supporting Information}

Supporting information for this article is available online at https://doi.org/10.1055/s-0040-1706022.

\section{References and Notes}

(1) (a) Langer, T.; Eder, M.; Hoffmann, R. D.; Chiba, P.; Ecker, G. F. Arch. Pharm. 2004, 337, 317. (b) Cheenpracha, S.; Karalai, C.; Ponglimanont, C.; Subhadhirasakul, S.; Tewtrakul, S. Bioorg. Med. Chem. 2006, 14, 1710. (c) Lowes, D. J.; Guiguemde, W. A.; Connelly, M.; Zhu, C. F.; Sigal, M. S.; Clark, J. A.; Lemoff, A. S.; Derisi, J. L.; Wilson, E. B.; Guy, R. K. J. Med. Chem. 2011, 54, 7477. 
(2) (a) Ohkuma, T.; Ooka, H.; Ikariya, T.; Noyori, R. J. Am. Chem. Soc. 1995, 117, 10417. (b) Shevlin, M.; Friedfeld, M. R.; Sheng, H.; Pierson, N. A.; Hoyt, J. M.; Campeau, L.-C.; Chirik, P. J. J. Am. Chem. Soc. 2016, 138, 3562. (c) Li, W.; Wu, X.-F. Eur. J. Org. Chem. 2015, 331. (d) Ding, B.; Zhang, Z.; Liu, Y.; Sugiya, M.; Imamoto, T.; Zhang, W. Org. Lett. 2013, 15, 3690. (e) Farrar-Tobar, R.; Wei, Z.; Jiao, H.; Hinze, S.; de Vries, J. G. Chem. Eur. J. 2018, 24, 2725. (f) Puylaert, P.; van Heck, R.; Fan, Y.; Spannenberg, A.; Baumann, W.; Beller, M.; Medlock, J.; Bonrath, W.; Lefort, L.; Hinze, S.; de Vries, J. G. Chem. Eur. J. 2017, 23, 8473.

(3) (a) Wang, D.; Astruc, D. Chem. Rev. 2015, 115, 6621. (b) Odendaal, A.; Trader, Y. D.; Carlson, J. E. E. Chem. Sci. 2011, 2, 760. (c) Volkov, A.; Tinnis, F.; Slagbrand, T.; Trilloa, P.; Adolfsson, H. Chem. Soc. Rev. 2016, 45, 6685. (d) Serna, P.; Corma, A. ACS Catal. 2015, 5, 7114.

(4) (a) Haskel, A.; Keinan, E. Handbook of Organopalladium Chemistry, Vol. 2; Negishi, E.-i.; de Meijere, A., Ed.; Wiley: New York, 2002, 2767. (b) Dupau, P. In Organometallics as Catalysts in the Fine Chemical Industry; Beller, M.; Blaser, H.-U., Ed.; Springer: Heidelberg, 2012, 47.

(5) (a) Rao, H. S. P.; Reddy, K. S. Tetrahedron Lett. 1994, 35, 171. (b) Yu, H.; Kang, R.; Ouyang, X. Chin. J. Org. Chem. 2000, 20, 441. (c) Luiza, M.; Holleben, A.; Zucolotto, M.; Zini, C. A.; Oliveira, E. R. Tetrahedron 1994, 50, 973. (d) Keinan, E.; Gleize, P. A. Tetrahedron Lett. 1982, 23, 477.

(6) (a) Albrecht, M. Chem. Rev. 2010, 110, 576. (b) Lu, H.; Yu, T.-Y.; Xu, P.-F.; Wei, H. Chem. Rev. 2021, 121, 365. (c) Petrone, D. A.; Ye, J.; Lautens, M. Chem. Rev. 2016, 116, 8003. (d) Xia, Y.; Qiu, D.; Wang, J. Chem. Rev. 2017, 117, 13810.

(7) (a) Guo, T.; Ding, Y.; Zhou, L.; Xu, H.; Loh, T.-P.; Wu, X. ACS Catal. 2020, 10, 7262. (b) Ramar, T.; Subbaiah, M. A. M.; Ilangovan, A. J. Org. Chem. 2020, 85, 7711.

(8) (a) Abooa, A. H.; Begum, R.; Zhao, L.; Farooqi, Z. H.; Xiao, J. Chin. J. Catal. 2019, 40, 1795. (b) Baán, Z.; Finta, Z.; Keglevich, G.; Hermecz, I. Green Chem. 2009, 11, 1937.

(9) Hu, X.; Wang, G.; Qin, C.; Xie, X.; Zhang, C.; Xua, W.; Liu, Y. Org. Chem. Front. 2019, 6, 2619.

(10) (a) Zhang, D.; Iwai, T.; Sawamura, M. Org. Lett. 2019, 21, 5867. (b) Wang, X.; Han, Z.; Wang, Z.; Ding, K. Angew. Chem. Int. Ed. 2012, 51, 936. (c) Császára, Z.; Szabóa, E. Z.; Bényeib, A. C.; Bakosa, J.; Farkas, G. Catal. Commun. 2020, 146, 106128.

(11) (a) Song, T.; Ma, Z.; Yang, Y. ChemCatChem 2019, 11, 1313. (b) Jiang, B.-L.; Ma, S.-S.; Wang, M.-L.; Liu, D.-S.; Xu, B.-H.; Zhang, S.-J. ChemCatChem 2019, 11, 1701. (c) Rösler, S.; Obenauf, J.; Kempe, R. J. Am. Chem. Soc. 2015, 137, 7998.

(12) (a) Babu Syamala, L. V. R.; Mete, T. B.; Bhat, R. G. Tetrahedron Lett. 2018, 59, 3288. (b) Lator, A.; Gaillard, S.; Poater, A.; Renaud, J.-L. Chem. Eur. J. 2018, 24, 5770. (c) Fleischer, S.; Zhou, S.; Junge, K.; Beller, M. Angew. Chem. Int. Ed. 2013, 52, 5120. (d) Wienhöfer, G.; Westerhaus, F. A.; Junge, K.; Ludwig, R.; Beller, M. Chem. Eur. J. 2013, 19, 7701.

(13) (a) Dahlen, A.; Hilmersson, G. Chem. Eur. J. 2003, 9, 1123. (b) Li, J.; Zhang, Y.-X.; Ji, Y. J. J. Chin. Chem. Soc. 2008, 55, 390.

(14) Prasanna, R.; Guha, S.; Sekar, G. Org. Lett. 2019, 21, 2650.

(15) (a) Lan, X.; Wang, T. ACS Catal. 2020, 10, 2764. (b) Garduño, J. A.; García, J. J. ACS Catal. 2020, 10, 8012. (c) Crespo-Quesada, M.; Cárdenas-Lizana, F.; Dessimoz, A.-L.; Kiwi-Minsker, L. ACS Catal. 2012, 2, 1773.

(16) (a) Wang, C.; Xiao, J. Chem. Commun. 2017, 53, 3399. (b) Michon, C.; MacIntyre, K.; Corre, Y.; Agbossou-Niedercorn, F. ChemCatChem 2016, 8, 1755. (c) Wu, X.; Xiao, J. Chem. Commun. 2007, 2449. (d) Lei, Q.; Wei, Y.; Talwar, D.; Wang, C.; Xue, D.; Xiao, J. Chem. Eur. J. 2013, 19, 4021. (e) Ouyang, L.; Xia, Y.; Liao, J.; Luo,
R. Eur. J. Org. Chem. 2020, 6387. (f) Pan, H.-J.; Zhang, Y.; Shan, C.; Yu, Z.; Lan, Y.; Zhao, Y. Angew. Chem. Int. Ed. 2016, 55, 9615. (g) Chen, Y.; Pan, Y.; He, Y.-M.; Fan, Q.-H. Angew. Chem. Int. Ed. 2019, 58, 16831. (h) Wei, Y.; Xue, D.; Lei, Q.; Wang, C.; Xiao, J. Green Chem. 2013, 15, 629. (i) Yang, Z.; Zhu, Z.; Luo, R.; Qiu, X.; Liu, J.; Yang, J.-K.; Tang, W. Green Chem. 2017, 19, 3296. (j) Li, J.; Tang, W.; Ren, D.; Xu, J.; Yang, Z. Green Chem. 2019, 21, 2088. (k) Luo, N.; Zhong, Y.; Liu, J.; Ouyang, L.; Luo, R. Synthesis 2020, $52,3439$.

(17) (a) Václavíková Vilhanová, B.; Budinská, A.; Václavík, J.; Matoušek, V.; Kuzma, M.; Červený, L. Eur. J. Org. Chem. 2017, 5131. (b) Yuan, S.; Gao, G.; Wang, L.; Liu, C.; Wan, L.; Huang, H.; Geng, H.; Chang, M. Nat. Commun. 2020, 11, 621. (c) Azran, J.; Buchman, O. Tetrahedron Lett. 1981, 22, 1925. (d) Higashino, T.; Sakaguchi, S.; Ishii, Y. Org. Lett. 2000, 2, 4193. (e) Zhang, D.; Iwai, T.; Sawanmura, M. Org. Lett. 2019, 21, 5867.

(18) (a) Hamid, M. H. S. A.; Slatford, P. A.; Williams, J. M. J. Adv. Synth. Catal. 2007, 349, 1555. (b) Guillena, G.; Ramón, D.; Yus, J. M. Chem. Rev. 2010, 110, 1611. (c) Irrgang, T.; Kempe, R. Chem. Rev. 2019, 119, 2524. (d) Reed-Berendt, B. G.; Polidano, K. L.; Morrill, C. Org. Biomol. Chem. 2019, 17, 1595. (e) Luo, N.; Zhong, Y.; Wen, H.; Luo, R. ACS Omega 2020, 5, 27723.

(19) (a) Mellmann, D.; Sponholz, P.; Junge, H.; Beller, M. Chem. Soc. Rev. 2016, 45, 3954. (b) Wang, W.-H.; Xu, S.; Manaka, Y.; Suna, Y.; Kambayashi, H. J.; Muckerman, T.; Fujita, E.; Himeda, Y. ChemSusChem 2014, 7, 1976. (c) Wang, Z.; Lu, S.-M.; Li, J.; Wang, J.; Li, C. Chem. Eur. J. 2015, 21, 12592.

(20) Luo, N.; Liao, J.; Ouyang, L.; Wen, H.; Liu, J.; Tang, W.; Luo, R. Organometallics 2019, 38, 3025.

(21) Procedure for the Preparation of 3

To a $25.0 \mathrm{~mL}$ dried Schlenk tube was added the $\alpha, \beta$-unsaturated ketone $(2,0.5 \mathrm{mmol})$, Ir catalyst $(1.0 \mathrm{~mol} \%), \mathrm{HCOOH}(10.0$ equiv), water $(2.0 \mathrm{~mL})$, and $\mathrm{MeOH}(2.0 \mathrm{~mL})$ successively. The mixture was stirred at room temperature for $12 \mathrm{~h}$ under air. After reaction was complete, the mixture was diluted with $\mathrm{H}_{2} \mathrm{O}$ $(15.0 \mathrm{~mL})$, neutralized with saturated aq. $\mathrm{NaHCO}_{3}$, and extracted with EtOAc $(3 \times 10.0 \mathrm{~mL})$. The combined organic layers were washed with brine $(3 \times 10.0 \mathrm{~mL})$ and dried over anhydrous $\mathrm{MgSO}_{4}$. After filtration and removal of the EtOAc under vacuum, the crude product was purified by column chromatography on silica gel, eluting with hexane or petroleum ether/ethyl acetate (10:1 to 50:1) to achieve the desired products.

\section{1,3-Diphenylpropan-1-one (3aa) $)^{12 b}$}

Yield 90\% (94.5 mg), pale yellow oil. ${ }^{1} \mathrm{H}$ NMR $\left(400 \mathrm{MHz}, \mathrm{CDCl}_{3}\right)$ : $\delta=8.00(\mathrm{~d}, J=7.8 \mathrm{~Hz}, 2 \mathrm{H}), 7.59(\mathrm{t}, J=7.3 \mathrm{~Hz}, 1 \mathrm{H}), 7.49(\mathrm{t}, J=7.7$ $\mathrm{Hz}, 2 \mathrm{H}$ ), 7.37-7.22 (m, $5 \mathrm{H}), 3.37-3.30(\mathrm{~m}, 2 \mathrm{H}), 3.14-3.07$ ( $\mathrm{m}, 2$ H). ${ }^{13} \mathrm{C}$ NMR $\left(100 \mathrm{MHz}, \mathrm{CDCl}_{3}\right): \delta=199.3,141.3,136.9,133.1$, 128.6, 128.6, 128.5, 128.1, 126.2, 40.5, 30.2. 1-Phenyl-3-(p-tolyl)propan-1-one (3ab) ${ }^{14}$

Yield 90\% (96.3 mg), pale yellow oil. ${ }^{1} \mathrm{H}$ NMR ( $\left.400 \mathrm{MHz}, \mathrm{CDCl}_{3}\right)$ : $\delta=7.98-7.92(\mathrm{~m}, 2 \mathrm{H}), 7.55(\mathrm{t}, J=7.4 \mathrm{~Hz}, 1 \mathrm{H}), 7.45(\mathrm{t}, J=7.7 \mathrm{~Hz}$, $2 \mathrm{H}), 7.13(\mathrm{q}, J=8.1 \mathrm{~Hz}, 4 \mathrm{H}), 3.31-3.24(\mathrm{~m}, 2 \mathrm{H}), 3.06-3.00(\mathrm{~m}, 2$ $\mathrm{H}), 2.32(\mathrm{~s}, 3 \mathrm{H}) .{ }^{13} \mathrm{C}$ NMR $\left(100 \mathrm{MHz}, \mathrm{CDCl}_{3}\right): \delta=199.4,138.2$, 136.9, 135.7, 133.1, 129.2, 128.6, 128.3, 128.1, 40.6, 29.7, 21.0. 1-Phenyl-3-(m-tolyl)propan-1-one (3ac) ${ }^{2 \mathrm{~d}}$

Yield $86 \%$ (95.2 mg), pale yellow oil. ${ }^{1} \mathrm{H}$ NMR (400 $\left.\mathrm{MHz}, \mathrm{CDCl}_{3}\right)$ : $\delta=7.96(\mathrm{~d}, J=7.5 \mathrm{~Hz}, 2 \mathrm{H}), 7.55(\mathrm{t}, J=7.3 \mathrm{~Hz}, 1 \mathrm{H}), 7.45(\mathrm{t}, J=7.6$ $\mathrm{Hz}, 2 \mathrm{H}), 7.19(\mathrm{t}, J=7.5 \mathrm{~Hz}, 1 \mathrm{H}), 7.04(\mathrm{dd}, J=13.2,9.1 \mathrm{~Hz}, 3 \mathrm{H})$, 3.33-3.26 (m, $2 \mathrm{H}), 3.06-2.99(\mathrm{~m}, 2 \mathrm{H}), 2.33(\mathrm{~s}, 3 \mathrm{H}) .{ }^{13} \mathrm{C}$ NMR $\left(100 \mathrm{MHz}, \mathrm{CDCl}_{3}\right): \delta=199.4,141.3,138.1,136.9,133.1,129.3$, 128.6, 128.5, 128.1, 126.9, 125.4, 40.6, 30.1, 21.4. 3-(2-Methoxyphenyl)-1-phenylpropan-1-one (3ad) ${ }^{14}$ Yield 85\% (102 mg), pale yellow oil. ${ }^{1} \mathrm{H}$ NMR (400 MHz, $\left.\mathrm{CDCl}_{3}\right)$ : 
$\delta=7.97(\mathrm{~d}, J=7.8 \mathrm{~Hz}, 2 \mathrm{H}), 7.53(\mathrm{t}, J=7.3 \mathrm{~Hz}, 1 \mathrm{H}), 7.43(\mathrm{t}, J=7.6$ $\mathrm{Hz}, 2 \mathrm{H}), 7.23-7.16(\mathrm{~m}, 2 \mathrm{H}), 6.92-6.81(\mathrm{~m}, 2 \mathrm{H}), 3.81(\mathrm{~s}, 3 \mathrm{H})$, 3.29-3.22 (m, $2 \mathrm{H}), 3.08-3.01(\mathrm{~m}, 2 \mathrm{H}) .{ }^{13} \mathrm{C}$ NMR $(100 \mathrm{MHz}$, $\left.\mathrm{CDCl}_{3}\right): \delta=200.0,157.6,137.0,132.9,130.2,129.6,128.6,128.2$, 127.6, 120.6, 110.3, 55.2, 39.0, 25.8.

3-(4-Chlorophenyl)-1-phenylpropan-1-one (3ae) ${ }^{\mathbf{1 4}}$

Yield 90\% (109.8 mg), colorless oil $\left(88.5-90{ }^{\circ} \mathrm{C}\right) .{ }^{1} \mathrm{H}$ NMR (400 $\left.\mathrm{MHz}, \mathrm{CDCl}_{3}\right): \delta=7.98-7.91(\mathrm{~m}, 2 \mathrm{H}), 7.56(\mathrm{t}, J=7.4 \mathrm{~Hz}, 1 \mathrm{H}), 7.45$ (t, $J=7.7 \mathrm{~Hz}, 2 \mathrm{H}), 7.28-7.24(\mathrm{~m}, 2 \mathrm{H}), 7.18(\mathrm{~d}, J=8.4 \mathrm{~Hz}, 2 \mathrm{H})$, $3.28(\mathrm{t}, J=7.5 \mathrm{~Hz}, 2 \mathrm{H}), 3.04(\mathrm{t}, J=7.5 \mathrm{~Hz}, 2 \mathrm{H}) .{ }^{13} \mathrm{C}$ NMR $(100$ $\left.\mathrm{MHz}, \mathrm{CDCl}_{3}\right): \delta=198.9,139.7,136.8,133.2,131.9,129.8,128.7$, 128.6, 128.0, 40.2, 29.4 .

\section{3-(4-Bromophenyl)-1-phenylpropan-1-one (3af) ${ }^{\mathbf{1 4}}$}

Yield 83\% (119.5 mg), colorless oil. ${ }^{1} \mathrm{H}$ NMR $\left(400 \mathrm{MHz}, \mathrm{CDCl}_{3}\right)$ : $\delta=8.04-7.95(\mathrm{~m}, 2 \mathrm{H}), 7.58(\mathrm{dd}, J=10.7,4.0 \mathrm{~Hz}, 2 \mathrm{H}), 7.48(\mathrm{t}, J=$ $7.6 \mathrm{~Hz}, 2 \mathrm{H}), 7.35$ (dd, $J=7.6,1.6 \mathrm{~Hz}, 1 \mathrm{H}), 7.27(\mathrm{td}, J=7.5,1.1 \mathrm{~Hz}$, $1 \mathrm{H}), 7.10$ (td, $J=7.7,1.7 \mathrm{~Hz}, 1 \mathrm{H}), 3.37-3.32(\mathrm{~m}, 2 \mathrm{H}), 3.24-3.19$ $(\mathrm{m}, 2 \mathrm{H}) .{ }^{13} \mathrm{C}$ NMR $\left(100 \mathrm{MHz}, \mathrm{CDCl}_{3}\right): \delta=198.9,140.6,136.8$, 133.2, 132.9, 130.8, 128.6, 128.1, 128.0, 127.7, 124.4, 38.6, 30.8. 3-(2,3-Difluorophenyl)-1-phenylpropan-1-one (3ag) Yield $81 \%$ (99.6 mg), pale yellow oil. ${ }^{1} \mathrm{H} \mathrm{NMR}\left(400 \mathrm{MHz}, \mathrm{CDCl}_{3}\right)$ : $\delta=8.01-7.95(\mathrm{~m}, 2 \mathrm{H}), 7.59(\mathrm{t}, J=7.4 \mathrm{~Hz}, 1 \mathrm{H}), 7.48(\mathrm{t}, J=7.7 \mathrm{~Hz}$, $2 \mathrm{H}), 7.08-6.98(\mathrm{~m}, 3 \mathrm{H}), 3.34(\mathrm{t}, J=7.5 \mathrm{~Hz}, 2 \mathrm{H}), 3.15(\mathrm{t}, J=7.5$ $\mathrm{Hz}, 2 \mathrm{H}) .{ }^{13} \mathrm{C}$ NMR $\left(100 \mathrm{MHz}, \mathrm{CDCl}_{3}\right): \delta=198.6,149.9$ (dd, $J=$ 243, $13 \mathrm{~Hz}), 136.6,133.2,130.6(\mathrm{~d}, J=12 \mathrm{~Hz}), 128.7,128.0$, $125.6(\mathrm{t}, J=4 \mathrm{~Hz}), 123.9(\mathrm{dd}, J=6,4 \mathrm{~Hz}), 115.2(\mathrm{~d}, J=17 \mathrm{~Hz})$, 38.6, 23.6.

3-(2,3-Dimethylphenyl)-1-phenylpropan-1-one (3ah)

Yield $86 \%$ (102.3 mg), colorless oil. ${ }^{1} \mathrm{H}$ NMR $\left(400 \mathrm{MHz}, \mathrm{CDCl}_{3}\right)$ : $\delta=8.00(\mathrm{~d}, J=7.6 \mathrm{~Hz}, 2 \mathrm{H}), 7.59(\mathrm{t}, J=7.4 \mathrm{~Hz}, 1 \mathrm{H}), 7.49(\mathrm{t}, J=7.6$ $\mathrm{Hz}, 2 \mathrm{H}), 7.11-7.05(\mathrm{~m}, 3 \mathrm{H}), 3.27$ (dd, $J=9.3,6.5 \mathrm{~Hz}, 2 \mathrm{H}), 3.15-$ $3.08(\mathrm{~m}, 2 \mathrm{H}), 2.33(\mathrm{~s}, 3 \mathrm{H}), 2.28(\mathrm{~s}, 3 \mathrm{H}) .{ }^{13} \mathrm{C}$ NMR $(100 \mathrm{MHz}$, $\left.\mathrm{CDCl}_{3}\right): \delta=199.5,139.3,137.1,136.9,134.6,133.1,128.6,128.1$, 128.1, 126.9, 125.6, 39.6, 28.3, 20.7, 15.1. ESI-HRMS: $m / z$ calcd for $\mathrm{C}_{17} \mathrm{H}_{19} \mathrm{O}[\mathrm{M}+\mathrm{H}]^{+}$: 239.1436; found: 239.1433 .

3-(Furan-2-yl)-1-phenylpropan-1-one (3ai) ${ }^{22 a}$

Yield $82 \%$ (82 mg), pale yellow oil. ${ }^{1} \mathrm{H}$ NMR $\left(400 \mathrm{MHz}, \mathrm{CDCl}_{3}\right)$ : $\delta=7.99-7.95(\mathrm{~m}, 2 \mathrm{H}), 7.56(\mathrm{t}, J=7.4 \mathrm{~Hz}, 1 \mathrm{H}), 7.45(\mathrm{t}, J=7.7 \mathrm{~Hz}$, $2 \mathrm{H}), 7.33-7.28(\mathrm{~m}, 1 \mathrm{H}), 6.30-6.25(\mathrm{~m}, 1 \mathrm{H}), 6.05(\mathrm{~d}, J=3.1 \mathrm{~Hz}, 1$ $\mathrm{H}), 3.35-3.31(\mathrm{~m}, 2 \mathrm{H}), 3.11-3.07(\mathrm{~m}, 2 \mathrm{H}) .{ }^{13} \mathrm{C}$ NMR (100 MHz, $\left.\mathrm{CDCl}_{3}\right): \delta=198.7,154.8,141.1,136.8,133.2,128.6,128.1,110.3$, 105.3, 36.9, 22.5 .

1-Phenyl-3-(thiophen-2-yl)propan-1-one (3aj) $)^{2 b}$

Yield $80 \%$ (86.4 mg), pale yellow oil. ${ }^{1} \mathrm{H}$ NMR (400 MHz, $\left.\mathrm{CDCl}_{3}\right)$ : $\delta=7.98-7.93(\mathrm{~m}, 2 \mathrm{H}), 7.55(\mathrm{t}, J=7.4 \mathrm{~Hz}, 1 \mathrm{H}), 7.45(\mathrm{t}, J=7.6 \mathrm{~Hz}$, $2 \mathrm{H}), 7.11(\mathrm{dd}, J=5.1,0.9 \mathrm{~Hz}, 1 \mathrm{H}), 6.91(\mathrm{dd}, J=5.0,3.5 \mathrm{~Hz}, 1 \mathrm{H})$, $6.85(\mathrm{~d}, J=3.1 \mathrm{~Hz}, 1 \mathrm{H}), 3.38-3.33(\mathrm{~m}, 2 \mathrm{H}), 3.31-3.26(\mathrm{~m}, 2 \mathrm{H})$. ${ }^{13} \mathrm{C}$ NMR $\left(100 \mathrm{MHz}, \mathrm{CDCl}_{3}\right): \delta=198.6,143.9,136.8,133.2,128.7$, 128.1, 126.9, 124.7, 123.4, 40.6, 24.2.

1-(4-Fluorophenyl)-3-phenylpropan-1-one (3ba) ${ }^{2 d}$

Yield $88 \%$ (100.3 mg), colorless oil. ${ }^{1} \mathrm{H}$ NMR $\left(400 \mathrm{MHz}, \mathrm{CDCl}_{3}\right)$ : $\delta=7.99-7.93(\mathrm{~m}, 2 \mathrm{H}), 7.32-7.18(\mathrm{~m}, 5 \mathrm{H}), 7.09(\mathrm{t}, J=8.6 \mathrm{~Hz}, 2$ $\mathrm{H}), 3.25(\mathrm{t}, J=7.7 \mathrm{~Hz}, 2 \mathrm{H}), 3.05(\mathrm{t}, J=7.6 \mathrm{~Hz}, 2 \mathrm{H}) .{ }^{13} \mathrm{C}$ NMR $(100$ $\left.\mathrm{MHz}, \mathrm{CDCl}_{3}\right): \delta=197.6,165.7(\mathrm{~d}, J=253 \mathrm{~Hz}), 141.2,133.3(\mathrm{~d}, J=$ $2 \mathrm{~Hz}), 130.7$ (d, $J=9 \mathrm{~Hz}), 128.60,128.5$ (d, $J=14 \mathrm{~Hz}), 126.2$, $115.7(\mathrm{~d}, J=22 \mathrm{~Hz}), 40.4$, 30.1. ESI-HRMS: $\mathrm{m} / z$ calcd for $\mathrm{C}_{15} \mathrm{H}_{14} \mathrm{OF}$ $[\mathrm{M}+\mathrm{H}]^{+}:$229.1029; found: 229.1030 .

\section{1-(4-Chlorophenyl)-3-phenylpropan-1-one (3bb) ${ }^{2 \mathrm{~d}}$}

Yield $84 \%$ (102.5 mg), colorless oil. ${ }^{1} \mathrm{H}$ NMR $\left(400 \mathrm{MHz}, \mathrm{CDCl}_{3}\right)$ : $\delta=7.91-7.86(\mathrm{~m}, 2 \mathrm{H}), 7.42(\mathrm{~d}, J=8.5 \mathrm{~Hz}, 2 \mathrm{H}), 7.31-7.20(\mathrm{~m}, 5$ H), 3.26 (dd, $J=10.0,5.3 \mathrm{~Hz}, 2 \mathrm{H}$ ), 3.06 (dd, $J=10.0,5.2 \mathrm{~Hz}, 2 \mathrm{H}$ ). ${ }^{13} \mathrm{C}$ NMR $\left(100 \mathrm{MHz}, \mathrm{CDCl}_{3}\right): \delta=198.0,141.1,139.5,135.2,129.5$, 128.9, 128.,6 128.4, 126.2, 40.4, 30.1 .
1-(4-Bromophenyl)-3-phenylpropan-1-one (3bc) ${ }^{2 \mathrm{~d}}$

Yield $83 \%$ (119.5 mg), yellow oil. ${ }^{1} \mathrm{H}$ NMR $\left(400 \mathrm{MHz}, \mathrm{CDCl}_{3}\right): \delta=$ $7.84(\mathrm{~d}, J=8.5 \mathrm{~Hz}, 2 \mathrm{H}), 7.61(\mathrm{~d}, J=8.5 \mathrm{~Hz}, 2 \mathrm{H}), 7.36-7.22(\mathrm{~m}, 5$ $\mathrm{H}), 3.29(\mathrm{t}, J=7.7 \mathrm{~Hz}, 2 \mathrm{H}), 3.09(\mathrm{t}, J=7.6 \mathrm{~Hz}, 2 \mathrm{H}) .{ }^{13} \mathrm{C}$ NMR $(100$ $\left.\mathrm{MHz}, \mathrm{CDCl}_{3}\right): \delta=198.2,141.1,135.6,131.9,129.6,128.6,128.4$, $128.3,126.3,40.4,30.1$.

\section{3-Phenyl-1-[4-(trifluoromethyl)phenyl]propan-1-one} (3bd) $)^{2 d}$

Yield 80\% (111.2 mg), yellow oil. ${ }^{1} \mathrm{H}$ NMR (400 MHz, $\left.\mathrm{CDCl}_{3}\right): \delta=$ $8.07(\mathrm{~d}, J=8.2 \mathrm{~Hz}, 2 \mathrm{H}), 7.74(\mathrm{~d}, J=8.3 \mathrm{~Hz}, 2 \mathrm{H}), 7.36-7.22(\mathrm{~m}, 5$ $\mathrm{H}), 3.35(\mathrm{t}, J=7.6 \mathrm{~Hz}, 2 \mathrm{H}), 3.11(\mathrm{t}, J=7.6 \mathrm{~Hz}, 2 \mathrm{H}) .{ }^{13} \mathrm{C} \mathrm{NMR}(100$ $\left.\mathrm{MHz}, \mathrm{CDCl}_{3}\right): \delta=198.2,140.9,139.5,134.6(\mathrm{q}, J=33 \mathrm{~Hz}), 128.6$, 128.4, 128.4, 126.3, $125.7(\mathrm{q}, J=4 \mathrm{~Hz}), 123.5(\mathrm{q}, J=258 \mathrm{~Hz}), 40.8$, 29.9.

1-(3-Bromo-4-fluorophenyl)-3-phenylpropan-1-one (3be) Yield $87 \%$ (133.1 mg), pale yellow oil. ${ }^{1} \mathrm{H}$ NMR $\left(400 \mathrm{MHz}, \mathrm{CDCl}_{3}\right)$ : $\delta=8.19(\mathrm{dd}, J=6.6,2.1 \mathrm{~Hz}, 1 \mathrm{H}), 7.92(\mathrm{ddd}, J=8.5,4.7,2.1 \mathrm{~Hz}, 1$ H), 7.36-7.30 (m, 2 H), 7.28-7.18 (m, $4 \mathrm{H}), 3.28(\mathrm{t}, J=7.6 \mathrm{~Hz}, 2$ $\mathrm{H}), 3.09(\mathrm{t}, J=7.6 \mathrm{~Hz}, 2 \mathrm{H}) .{ }^{13} \mathrm{C} \mathrm{NMR}\left(100 \mathrm{MHz}, \mathrm{CDCl}_{3}\right): \delta=196.5$, $162.0(\mathrm{~d}, J=244 \mathrm{~Hz}), 140.9,134.4(\mathrm{~d}, J=3 \mathrm{~Hz}), 134.0(\mathrm{~d}, J=1 \mathrm{~Hz})$, $129.2(\mathrm{~d}, J=8 \mathrm{~Hz}), 128.6,128.4,126.3,116.7(\mathrm{~d}, J=23 \mathrm{~Hz}), 109.9$ $(\mathrm{d}, J=22 \mathrm{~Hz}), 40.4,30.0$. ESI-HRMS $m / z$ calcd for $\mathrm{C}_{15} \mathrm{H}_{13} \mathrm{OBrF}[\mathrm{M}$ $+\mathrm{H}]^{+}:$307.0134; found: 307.0135.

1-(4-Nitrophenyl)-3-phenylpropan-1-one (3bf) $)^{22 c}$

Yield $81 \%$ (103.3 mg), colorless oil. ${ }^{1} \mathrm{H}$ NMR (400 MHz, $\left.\mathrm{CDCl}_{3}\right)$ : $\delta=8.32(\mathrm{~d}, J=8.8 \mathrm{~Hz}, 2 \mathrm{H}), 8.11(\mathrm{~d}, J=8.8 \mathrm{~Hz}, 2 \mathrm{H}), 7.36-7.30(\mathrm{~m}$, $2 \mathrm{H}$ ), 7.27 (dd, $J=11.1,4.1 \mathrm{~Hz}, 3 \mathrm{H}), 3.37$ (t, $J=7.6 \mathrm{~Hz}, 2 \mathrm{H}), 3.12$ $(\mathrm{t}, J=7.5 \mathrm{~Hz}, 2 \mathrm{H}) .{ }^{13} \mathrm{C}$ NMR $\left(100 \mathrm{MHz}, \mathrm{CDCl}_{3}\right): \delta=197.7,150.3$, 141.3, 140.6, 129.1, 128.7, 128.4, 126.4, 123.9, 41.0, 29.9.

3-Phenyl-1-(p-tolyl)propan-1-one (3bg) ${ }^{2 \mathrm{~d}}$

Yield $90 \%(100.8 \mathrm{mg})$, colorless oil. ${ }^{1} \mathrm{H}$ NMR $\left(400 \mathrm{MHz}, \mathrm{CDCl}_{3}\right)$ : $\delta=7.90(\mathrm{~d}, J=8.2 \mathrm{~Hz}, 2 \mathrm{H}), 7.36-7.23(\mathrm{~m}, 7 \mathrm{H}), 3.34-3.28(\mathrm{~m}, 2$ $\mathrm{H}), 3.13-3.07(\mathrm{~m}, 2 \mathrm{H}), 2.44(\mathrm{~s}, 3 \mathrm{H}) .{ }^{13} \mathrm{C}$ NMR $\left(100 \mathrm{MHz}, \mathrm{CDCl}_{3}\right)$ : $\delta=198.9,143.9,141.4,134.4,129.3,128.6,128.5,128.2,126.1$, $40.4,30.3,21.7$.

1-(4-Methoxyphenyl)-3-phenylpropan-1-one (3bh) ${ }^{14}$

Yield 92\% (110.4 mg), colorless oil. ${ }^{1} \mathrm{H}$ NMR (400 MHz, $\left.\mathrm{CDCl}_{3}\right)$ : $\delta=7.72(\mathrm{dd}, J=7.7,1.7 \mathrm{~Hz}, 1 \mathrm{H}), 7.51-7.46(\mathrm{~m}, 1 \mathrm{H}), 7.28(\mathrm{dq}, J=$ 21.7, 7.4 Hz, $5 \mathrm{H}), 7.06-6.97(\mathrm{~m}, 2 \mathrm{H}), 3.91(\mathrm{~s}, 3 \mathrm{H}), 3.37-3.31$ $(\mathrm{m}, 2 \mathrm{H}), 3.09-3.03(\mathrm{~m}, 2 \mathrm{H}) .{ }^{13} \mathrm{C}$ NMR $\left(100 \mathrm{MHz}, \mathrm{CDCl}_{3}\right): \delta=$ 201.8, 158.6, 141.8, 133.5, 130.4, 128.5, 128.4, 128.3, 125.9, $120.7,111.5,55.5,45.5,30.5$.

3-Phenyl-1-(thiophen-2-yl)propan-1-one (3bi) $)^{12 b}$

Yield $87 \%$ (94.0 mg), pale yellow oil. ${ }^{1} \mathrm{H}$ NMR (400 $\left.\mathrm{MHz}, \mathrm{CDCl}_{3}\right)$ : $\delta=7.72(\mathrm{~d}, J=3.8 \mathrm{~Hz}, 1 \mathrm{H}), 7.65(\mathrm{~d}, J=4.9 \mathrm{~Hz}, 1 \mathrm{H}), 7.36-7.27(\mathrm{~m}$, $4 \mathrm{H}), 7.24(\mathrm{t}, J=7.5 \mathrm{~Hz}, 1 \mathrm{H}), 7.14(\mathrm{t}, J=4.3 \mathrm{~Hz}, 1 \mathrm{H}), 3.29-3.24$ $(\mathrm{m}, 2 \mathrm{H}), 3.13-3.08(\mathrm{~m}, 2 \mathrm{H}) .{ }^{13} \mathrm{C}$ NMR $\left(100 \mathrm{MHz}, \mathrm{CDCl}_{3}\right): \delta=$ $192.2,144.2,141.0,133.6,131.9,128.6,128.5,128.1,126.3$, $41.2,30.4$.

1-(Furan-2-yl)-3-phenylpropan-1-one (3bj) $)^{12 b}$

Yield $81 \%$ (89.1 mg), pale yellow oil. ${ }^{1} \mathrm{H}$ NMR ( $400 \mathrm{MHz}, \mathrm{CDCl}_{3}$ ): $\delta=7.59(\mathrm{~d}, J=0.9 \mathrm{~Hz}, 1 \mathrm{H}), 7.34-7.19(\mathrm{~m}, 6 \mathrm{H}), 6.54(\mathrm{dd}, J=3.5$, $1.6 \mathrm{~Hz}, 1 \mathrm{H}), 3.21-3.16$ (m, $2 \mathrm{H}), 3.07$ (dd, $J=9.7,5.3 \mathrm{~Hz}, 2 \mathrm{H}) .{ }^{13} \mathrm{C}$ NMR $\left(100 \mathrm{MHz}, \mathrm{CDCl}_{3}\right): \delta=188.5,152.7,146.4,141.0,128.5$, $128.4,126.2,117.1,112.2,40.2,30.0$.

1-(Naphthalen-1-yl)-3-phenylpropan-1-one (3bk) ${ }^{\mathbf{1 4}}$ Yield 93\% (120.9 mg), colorless oil. ${ }^{1} \mathrm{H}$ NMR (400 MHz, $\left.\mathrm{CDCl}_{3}\right): \delta$ $=8.60(\mathrm{~d}, J=8.5 \mathrm{~Hz}, 1 \mathrm{H}), 8.01(\mathrm{~d}, J=8.2 \mathrm{~Hz}, 1 \mathrm{H}), 7.91(\mathrm{~d}, J=7.9$ $\mathrm{Hz}, 1 \mathrm{H}), 7.85(\mathrm{~d}, J=7.2 \mathrm{~Hz}, 1 \mathrm{H}), 7.64-7.55(\mathrm{~m}, 2 \mathrm{H}), 7.50(\mathrm{t}, J=$ $7.7 \mathrm{~Hz}, 1 \mathrm{H}), 7.31(\mathrm{dq}, J=12.0,7.3 \mathrm{~Hz}, 5 \mathrm{H}), 3.42(\mathrm{t}, J=7.7 \mathrm{~Hz}, 2$ $\mathrm{H}), 3.18(\mathrm{t}, J=7.6 \mathrm{~Hz}, 2 \mathrm{H}) .{ }^{13} \mathrm{C} \mathrm{NMR}\left(100 \mathrm{MHz}, \mathrm{CDCl}_{3}\right): \delta=203.6$, $141.2,136.0,134.0,132.6,130.2,128.6,128.5,128.5,127.9$, $127.5,126.5,126.2,125.8,124.4,43.9,30.6$. 
(E)-5-Phenyl-1-(2,6,6-trimethylcyclohex-2-en-1-yl)pent-1en-3-one (3bl)

Yield 78\% (110.0 mg), colorless oil. ${ }^{1} \mathrm{H}$ NMR $\left(400 \mathrm{MHz}, \mathrm{CDCl}_{3}\right)$ : $\delta=7.36-7.18(\mathrm{~m}, 7 \mathrm{H}), 6.15(\mathrm{~d}, J=16.3 \mathrm{~Hz}, 1 \mathrm{H}), 2.96(\mathrm{td}, J=$ $14.1,6.9 \mathrm{~Hz}, 4 \mathrm{H}), 2.08(\mathrm{t}, J=6.0 \mathrm{~Hz}, 2 \mathrm{H}), 1.76(\mathrm{~s}, 3 \mathrm{H}), 1.65(\mathrm{~d}, J=$ $2.8 \mathrm{~Hz}, 1 \mathrm{H}), 1.49$ (d, J = 5.6 Hz, $2 \mathrm{H}), 1.07$ (s, $6 \mathrm{H}) .{ }^{13} \mathrm{C}$ NMR (100 $\left.\mathrm{MHz}, \mathrm{CDCl}_{3}\right): \delta=199.7,142.5,141.4,136.2,136.0,130.5,128.5$, $128.4,126.1,42.2,39.7,34.1,33.6,30.4,28.8,21.8,18.9$. ESIHRMS $\mathrm{m} / \mathrm{z}$ calcd for $\mathrm{C}_{20} \mathrm{H}_{27} \mathrm{O}[\mathrm{M}+\mathrm{H}]^{+}:$283.2062; found: 283.2064.
1,5-Diphenylpentan-3-one (3bm) $)^{22 \mathrm{~d}}$

Yield 76\% (90.4 mg), colorless oil. ${ }^{1} \mathrm{H} \mathrm{NMR}\left(400 \mathrm{MHz}, \mathrm{CDCl}_{3}\right): \delta=$ $7.31(\mathrm{t}, J=7.4 \mathrm{~Hz}, 4 \mathrm{H}), 7.22(\mathrm{dd}, J=17.0,7.3 \mathrm{~Hz}, 6 \mathrm{H}), 2.93(\mathrm{t}, J=$ $7.6 \mathrm{~Hz}, 4 \mathrm{H}), 2.75$ (dd, $J=9.7,5.5 \mathrm{~Hz}, 4 \mathrm{H}) .{ }^{13} \mathrm{C}$ NMR $(100 \mathrm{MHz}$, $\left.\mathrm{CDCl}_{3}\right): \delta=209.2,141.0,128.5,128.3,126.1,44.5,29.8$

(22) (a) Seck, C.; Mbaye, M. D.; Coufourier, S.; Lator, A.; Lohier, J.-F.; Poater, A.; Ward, T. R.; Gaillard, S.; Renaud, J.-L. ChemCatChem 2017, 9, 4410. (b) Li, P.; Xiao, G.; Zhao, Y.; Su, H. ACS Catal. 2020, 10, 3640. (c) Kim, H.-S.; Lee, S.-J.; Yoon, C.-M. Bull. Korean Chem. Soc. 2013, 34, 325. (d) Mohan, K. J.; Purnima, S. Chem. Soc. Jpn. 2004, 77, 549 . 